\title{
Action Research Applied in Structural Teaching Materials for Multimedia Programming Course
}

\author{
Chun-Tsai Wu ${ }^{1}$, Szu-Ming Chung ${ }^{2}$
}

\begin{abstract}
Teaching strategy, materials and objects have great influences on student attainment. For digital content design students, the multimedia programming is a complicated and difficult subject to learn. This study is an action research which goes through the process of reflection, action, and evaluation to explore the adaptive programming course. The reflective interview of programming teachers confirms the sequential form of teaching ActionScript 3.0 to influence the learning. It has adopted a methodology combining Interpretive Structural Modeling (ISM) and modified Delphi Method to investigate the teaching experience of programming teachers. The results were used to establish learning path and map fitting the learning style of design students. Such a learning path and map was also used to design teaching model implemented in class teaching. It proved that adaptive sequential teaching form can advance students' capabilities of integration and application.
\end{abstract}

Keywords: Interpretive Structural Modeling (ISM) • Modified Delphi method • pedagogical issues • teaching/learning strategies

\section{Introduction}

Teaching methods and materials affect learning anticipation. To have the best academic achievement, the educators must adopt suitable teaching strategy fitting student's learning style. Demonstrating a clear path of learning can also help continuous learning. Teacher's experience is a determining factor in teaching. This research study focuses on teaching digital content design students the ActionScript 3.0. The researchers have divided teaching content into 21 essential teaching elements and categorized them as a relational table of teaching elements using Interpretive Structural Modeling (ISM). Five programming teachers were interviewed about personal teaching strategy. Each one was asked to judge the relations of elements through ISM to establish a personal teaching hierarchy diagram. They examined the analysis results to match their own concept. By applying the modified Delphi method, the majority of the 5 teachers arrived at a consensus, and then a final relational table of teaching elements was established. This process was repeated until the the final teaching hierarchy diagram was constructed and used to design the ActionScript 3.0 teaching unit and examples. This pilot study initiated a series of research on a teaching plan, activity, observation, and reflection.

\footnotetext{
${ }^{1}$ Chun-Tsai Wu $(\square)$

Department of Digital Content Design, Ling Tung University, 1, Ling Tung Rd., Taichung, Taiwan, R.O.C

e-mail: ltctht53@teamail.ltu.edu.tw

2 Szu-Ming Chung $(\bowtie)$

Department of Digital Content Design, Ling Tung University, 1, Ling Tung Rd., Taichung, Taiwan, R.O.C

e-mail: Szuming@teamail.ltu.edu.tw
} 


\section{Related research and applications}

\subsection{Interpretive structural modeling}

Interpretive Structural Modeling (ISM) was developed by Warfield [17, 18]. It is an analytic method transferring subjective judgments of interrelationship, associating class diagrams, and also an effective tool clarifying complicated issues or solving problems between individuals and groups [7]. Many studies have used ISM to solve problems of providers' selection [4], risk analyses [9] and education [3, 14]. ISM was derived from discrete mathematics and graph theory, and whose processing steps derived from personal and group mental models. This study adopted ISM to construct complicated structural model of a teaching plan, and also examined if applicable in target analysis and developing teaching materials.

\subsection{Modified Delphi method}

In the 1950s the American company RAND developed Delphi method mainly implementing continuous intensive survey and feedback control to attain consensus and reliable views $[1,16]$. Many decision-making examples often emerged in industry and commerce [13], public policy [5, 11], psychological pre-testing [10], and education [15]. Traditionally, the Delphi method investigated the selected experts' views by repeating surveys and modifications. It was a complex and time consuming procedure. Later, the Delphi method was continuously modified to comply with different needs.

\subsection{Participants}

Five programming teachers and 67 students took part in this action research. They were selected from the department of Digital Content Design at Ling Tung University (Taichung, Taiwan).

\subsection{Research methodology}

An action research is a systematic study carried out by teacher-researchers and teaching environment stakeholders [2, 8]. It is a collective self-reflection. Hendricks [2] advocated that action research includes a cyclic process of reflection, action, and evaluation. Sagor [12] divided them into four stages: 1. clarifying vision and targets; 2. articulating theory; 3. implementing action and collecting data; 4. reflecting on data and planning informed action.

Based on Sagor's [12] action research, this study was designed as: 1. identifying teaching essentials; 2. interviewing experts to obtain consensus of interrelationships: interviewing experts by ISM analysis to collect teaching essentials matched with their mental concept and then constructing Adjacency Matrix; and using the modified Delphi method to obtain consensus of interrelationships of 21 essentials, and then constructing a hierarchy diagram; 3. developing teaching materials and implementing class teaching; 4. evaluating implementation results: writing teaching journal, observing daily learning and e-portfolios, evaluating the plan of teaching materials impact on learning attainment; the researchers refer these reflections to the future planning (Fig. 1). 


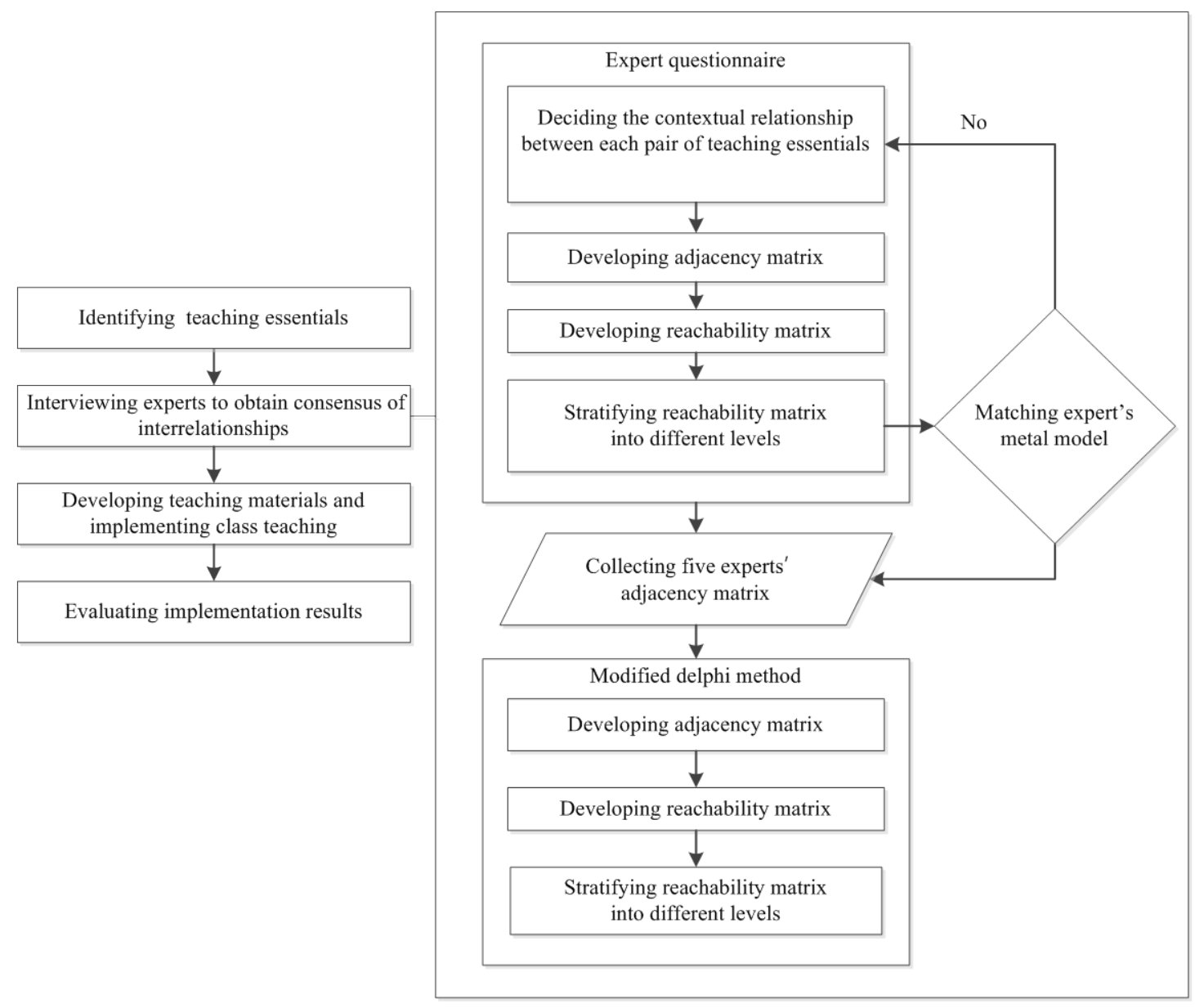

Fig. 1 Flowchart of action research

\subsubsection{Identifying teaching essentials}

In the initiative stage, through reflective interviews of programming teachers, all of them believed that teaching should be based on some sequence and form which affects students' learning attainment. A well-planned teaching design was needed and they jointly confirmed the teaching elements. Twenty one teaching essentials were listed from "a" to " $\mathrm{u}$ ".

\subsubsection{Interviewing experts to obtain consensus of interrelationships}

On second stage, the expert teachers used Table 1 to evaluate the correlation of the 21 teaching essentials received by e-mail with guidelines and an Excel example. Each teacher had his/her own ideas about the sequence of teaching. By comparing, preceding item was marked down as 1 or otherwise 0; if the paring items did not relate to each other, then it was left blank. For example, if the essential h (working with movieclips) preceded the essential i (display programming), then the expert filled in 1 of the crossed box of $h$ and $i$. During this stage, the completed tables established interrelations by interviewee's teaching experience.

Table 1. The evaluation table of the 21 essentials

\begin{tabular}{ccccccccccccccccccccccc}
\hline & $\mathbf{a}$ & $\mathbf{b}$ & $\mathbf{c}$ & $\mathbf{d}$ & $\mathbf{e}$ & $\mathbf{f}$ & $\mathbf{g}$ & $\mathbf{h}$ & $\mathbf{i}$ & $\mathbf{j}$ & $\mathbf{k}$ & $\mathbf{l}$ & $\mathbf{m}$ & $\mathbf{n}$ & $\mathbf{o}$ & $\mathbf{p}$ & $\mathbf{q}$ & $\mathbf{r}$ & $\mathbf{s}$ & $\mathbf{t}$ & $\mathbf{u}$ \\
\hline $\mathrm{a}$ & 0 & 1 & 1 & 1 & 1 & 1 & 1 & 1 & 1 & 1 & 1 & 1 & 1 & 1 & 1 & 1 & 1 & 1 & 1 & 1 & 1 \\
\hline $\mathrm{b}$ & 0 & 0 & 1 & 0 & 1 & 1 & 1 & 1 & 1 & 1 & 0 & 1 & 1 & 1 & 1 & 1 & 1 & 1 & 1 & 1 & 1 \\
\hline $\mathrm{c}$ & 0 & 0 & 0 & 0 & 0 & 0 & 1 & 0 & 1 & 0 & 0 & 0 & 0 & 0 & 1 & 1 & 1 & 1 & 0 & 0 & 1 \\
\hline
\end{tabular}




\begin{tabular}{cccccccccccccccccccccc}
\hline $\mathrm{d}$ & 0 & 0 & 0 & 0 & 0 & 1 & 0 & 0 & 0 & 1 & 0 & 1 & 1 & 1 & 0 & 0 & 0 & 0 & 0 & 0 & 1 \\
\hline $\mathrm{e}$ & 0 & 0 & 0 & 0 & 0 & 1 & 0 & 1 & 0 & 0 & 0 & 0 & 0 & 1 & 1 & 1 & 1 & 1 & 1 & 1 & 1 \\
\hline $\mathrm{f}$ & 0 & 0 & 0 & 0 & 0 & 0 & 1 & 0 & 0 & 0 & 1 & 0 & 1 & 0 & 0 & 1 & 0 & 0 & 1 & 1 & 1 \\
\hline $\mathrm{g}$ & 0 & 0 & 0 & 0 & 0 & 0 & 0 & 0 & 0 & 0 & 0 & 0 & 0 & 0 & 0 & 0 & 0 & 0 & 0 & 1 & 1 \\
\hline $\mathrm{h}$ & 0 & 0 & 0 & 0 & 0 & 0 & 0 & 0 & 1 & 1 & 0 & 0 & 0 & 1 & 0 & 0 & 1 & 0 & 1 & 1 & 1 \\
\hline $\mathrm{i}$ & 0 & 0 & 0 & 0 & 0 & 0 & 0 & 0 & 0 & 1 & 0 & 0 & 0 & 1 & 1 & 1 & 1 & 1 & 1 & 1 & 1 \\
\hline $\mathrm{j}$ & 0 & 0 & 0 & 0 & 0 & 0 & 0 & 0 & 0 & 0 & 0 & 0 & 0 & 0 & 0 & 0 & 0 & 0 & 0 & 0 & 1 \\
\hline $\mathrm{k}$ & 0 & 0 & 0 & 0 & 0 & 0 & 0 & 0 & 0 & 0 & 0 & 0 & 0 & 0 & 0 & 0 & 0 & 0 & 0 & 1 & 1 \\
\hline $\mathrm{l}$ & 0 & 0 & 0 & 0 & 0 & 0 & 0 & 0 & 0 & 0 & 0 & 0 & 1 & 1 & 1 & 1 & 1 & 1 & 1 & 1 & 1 \\
\hline $\mathrm{m}$ & 0 & 0 & 0 & 0 & 0 & 0 & 0 & 0 & 0 & 0 & 0 & 0 & 0 & 0 & 0 & 0 & 0 & 1 & 0 & 0 & 1 \\
\hline $\mathrm{n}$ & 0 & 0 & 0 & 0 & 0 & 0 & 0 & 0 & 0 & 0 & 0 & 0 & 0 & 0 & 0 & 0 & 0 & 0 & 1 & 0 & 1 \\
\hline $\mathrm{o}$ & 0 & 0 & 0 & 0 & 0 & 0 & 0 & 0 & 0 & 0 & 0 & 0 & 0 & 0 & 0 & 1 & 0 & 0 & 0 & 0 & 1 \\
\hline $\mathrm{p}$ & 0 & 0 & 0 & 0 & 0 & 0 & 0 & 0 & 0 & 0 & 0 & 0 & 0 & 0 & 0 & 0 & 0 & 0 & 0 & 0 & 1 \\
\hline $\mathrm{q}$ & 0 & 0 & 0 & 0 & 0 & 0 & 0 & 0 & 0 & 0 & 0 & 0 & 0 & 0 & 0 & 0 & 0 & 0 & 1 & 0 & 1 \\
\hline $\mathrm{r}$ & 0 & 0 & 0 & 0 & 0 & 0 & 0 & 0 & 0 & 0 & 0 & 0 & 0 & 0 & 0 & 0 & 0 & 0 & 0 & 0 & 1 \\
\hline $\mathrm{s}$ & 0 & 0 & 0 & 0 & 0 & 0 & 0 & 0 & 0 & 0 & 0 & 0 & 0 & 0 & 0 & 0 & 0 & 0 & 0 & 0 & 1 \\
\hline $\mathrm{t}$ & 0 & 0 & 0 & 0 & 0 & 0 & 0 & 0 & 0 & 0 & 0 & 0 & 0 & 0 & 0 & 0 & 0 & 0 & 0 & 0 & 1 \\
\hline $\mathrm{u}$ & 0 & 0 & 0 & 0 & 0 & 0 & 0 & 0 & 0 & 0 & 0 & 0 & 0 & 0 & 0 & 0 & 0 & 0 & 0 & 0 & 0 \\
\hline $\mathrm{Ess}$ & & & & & & & & & & & & & & & & & & & &
\end{tabular}

\section{Essentials}

a:ActionScript language and syntax; b:Working with objects; c:Handling events; d:Conditionals; e:Capturing user input; f:Working with strings; g:working with text; h:Working with movieclips; i:Display programming; j:Working with geometry; k:Working with arrays; l:Functions; m:Working with dates and times; Math class; n:Working with sound; o:Working with bitmaps; p:Filtering display objects; q:Working with video; r:Using the drawing API; s:External devices; t:Working with XML; u:Object-oriented programming in ActionScript

ISM analysis was carried out in 5 steps:

Step 1. Table 1 was offered to each teacher for examining and rating their views.

Step 2. Table 1 was transformed into an adjacency matrix. The following "A" represents the mathematic binary adjacency matrix transformed from an interrelation matrix.

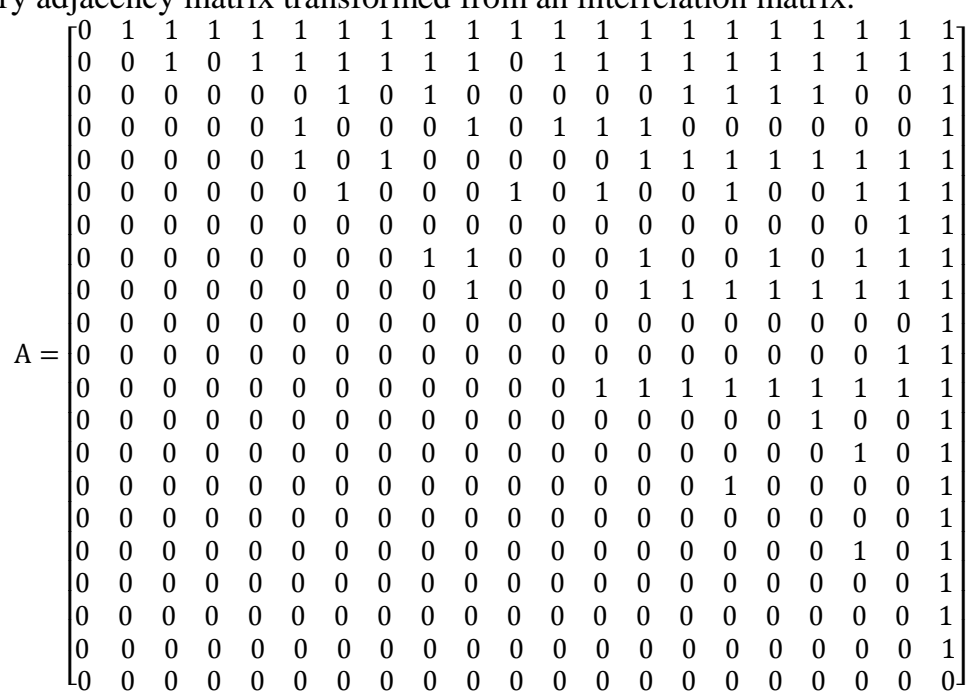

$=\left[s_{i j}\right],(i=1,2, \cdots 21 ; j=1,2, \cdots 21)$

Where, $s_{\mathrm{i}} \overline{\mathrm{R}} \mathrm{s}_{\mathrm{j}}=0, \mathrm{~s}_{\mathrm{i}} \mathrm{Rs}_{\mathrm{j}}=1$

and $s_{i} \bar{R} s_{j}=s_{i} R s_{j}=0$ if $s_{i}=s_{j}$

Step 3. The adjacency matrix was transformed to a Reachability matrix. The adjacency matrix was added to the unit matrix I and then transformed to a matrix with its own causal relationship. The following B represents such an interrelated matrix.

$\mathrm{B}=\mathrm{A}+\mathrm{I}$, where $\mathrm{A}=$ adjacency matrix, $\mathrm{I}=$ unit matrix, then transforming $\mathrm{B}$ to a reachability matrix by Boolean algebra algorithms, $\mathrm{M}$. The operation is:

$$
\begin{gathered}
\mathrm{B} \neq \mathrm{B}^{2} \neq \cdots \neq \mathrm{B}^{\mathrm{n}-1}=\mathrm{B}^{\mathrm{n}} \\
\mathrm{M}=\mathrm{B}^{\mathrm{n}}
\end{gathered}
$$


Excel aids to format the math macros. The final result is $\mathrm{B}^{9}=\mathrm{B}^{8} \times \mathrm{B}=\mathrm{M}$, which is a reachability matrix.

$\mathrm{M}=\left[\begin{array}{lllllllllllllllllllll}1 & 1 & 1 & 1 & 1 & 1 & 1 & 1 & 1 & 1 & 1 & 1 & 1 & 1 & 1 & 1 & 1 & 1 & 1 & 1 & 1 \\ 0 & 1 & 1 & 0 & 1 & 1 & 1 & 1 & 1 & 1 & 1 & 1 & 1 & 1 & 1 & 1 & 1 & 1 & 1 & 1 & 1 \\ 0 & 0 & 1 & 0 & 0 & 0 & 1 & 0 & 1 & 1 & 0 & 0 & 0 & 1 & 1 & 1 & 1 & 1 & 1 & 1 & 1 \\ 0 & 0 & 0 & 1 & 0 & 1 & 1 & 0 & 0 & 1 & 1 & 1 & 1 & 1 & 1 & 1 & 1 & 1 & 1 & 1 & 1 \\ 0 & 0 & 0 & 0 & 1 & 1 & 1 & 1 & 1 & 1 & 1 & 0 & 1 & 1 & 1 & 1 & 1 & 1 & 1 & 1 & 1 \\ 0 & 0 & 0 & 0 & 0 & 1 & 1 & 0 & 0 & 0 & 1 & 0 & 1 & 0 & 0 & 1 & 0 & 1 & 1 & 1 & 1 \\ 0 & 0 & 0 & 0 & 0 & 0 & 1 & 0 & 0 & 0 & 0 & 0 & 0 & 0 & 0 & 0 & 0 & 0 & 0 & 1 & 1 \\ 0 & 0 & 0 & 0 & 0 & 0 & 0 & 1 & 1 & 1 & 0 & 0 & 0 & 1 & 1 & 1 & 1 & 1 & 1 & 1 & 1 \\ 0 & 0 & 0 & 0 & 0 & 0 & 0 & 0 & 1 & 1 & 0 & 0 & 0 & 1 & 1 & 1 & 1 & 1 & 1 & 1 & 1 \\ 0 & 0 & 0 & 0 & 0 & 0 & 0 & 0 & 0 & 1 & 0 & 0 & 0 & 0 & 0 & 0 & 0 & 0 & 0 & 0 & 1 \\ 0 & 0 & 0 & 0 & 0 & 0 & 0 & 0 & 0 & 0 & 1 & 0 & 0 & 0 & 0 & 0 & 0 & 0 & 0 & 1 & 1 \\ 0 & 0 & 0 & 0 & 0 & 0 & 0 & 0 & 0 & 0 & 0 & 1 & 1 & 1 & 1 & 1 & 1 & 1 & 1 & 1 & 1 \\ 0 & 0 & 0 & 0 & 0 & 0 & 0 & 0 & 0 & 0 & 0 & 0 & 1 & 0 & 0 & 0 & 0 & 1 & 0 & 0 & 1 \\ 0 & 0 & 0 & 0 & 0 & 0 & 0 & 0 & 0 & 0 & 0 & 0 & 0 & 1 & 0 & 0 & 0 & 0 & 1 & 0 & 1 \\ 0 & 0 & 0 & 0 & 0 & 0 & 0 & 0 & 0 & 0 & 0 & 0 & 0 & 0 & 1 & 1 & 0 & 0 & 0 & 0 & 1 \\ 0 & 0 & 0 & 0 & 0 & 0 & 0 & 0 & 0 & 0 & 0 & 0 & 0 & 0 & 0 & 1 & 0 & 0 & 0 & 0 & 1 \\ 0 & 0 & 0 & 0 & 0 & 0 & 0 & 0 & 0 & 0 & 0 & 0 & 0 & 0 & 0 & 0 & 1 & 0 & 1 & 0 & 1 \\ 0 & 0 & 0 & 0 & 0 & 0 & 0 & 0 & 0 & 0 & 0 & 0 & 0 & 0 & 0 & 0 & 0 & 1 & 0 & 0 & 1 \\ 0 & 0 & 0 & 0 & 0 & 0 & 0 & 0 & 0 & 0 & 0 & 0 & 0 & 0 & 0 & 0 & 0 & 0 & 1 & 0 & 1 \\ 0 & 0 & 0 & 0 & 0 & 0 & 0 & 0 & 0 & 0 & 0 & 0 & 0 & 0 & 0 & 0 & 0 & 0 & 0 & 1 & 1 \\ 0 & 0 & 0 & 0 & 0 & 0 & 0 & 0 & 0 & 0 & 0 & 0 & 0 & 0 & 0 & 0 & 0 & 0 & 0 & 0 & 1\end{array}\right]$

Step 4. The reachability matrix was transformed to a hierarchical reachability matrix with levels. The definitions are listed as below:

$\mathrm{s}_{\mathrm{i}}$ represents the teaching essentials, $\mathrm{s}_{\mathrm{i}}=1,2,3 \cdots \mathrm{n}$

Taking out all 1 s from the intersection cells in the reachability matrix makes a reachability set $R\left(s_{i}\right)$.

$\mathrm{Q}\left(\mathrm{s}_{\mathrm{i}}\right)$ is the antecedent set.

$\mathrm{R}\left(\mathrm{s}_{\mathrm{i}}\right) \cap \mathrm{Q}\left(\mathrm{s}_{\mathrm{i}}\right)$ intersects the above two sets.

$s_{i}$ satisfying with $R\left(s_{i}\right) \cap Q\left(s_{i}\right)=R\left(s_{i}\right) s_{i}$ belongs to the same level. All rows and columns with $R\left(s_{i}\right)$ must be deleted until the number of the essentials is 0 . The final results of 8 levels are listed in

Table 2.

Table 2. Reachability Matrix with levels

\begin{tabular}{|c|c|c|c|c|}
\hline & $\mathrm{R}\left(\mathrm{s}_{\mathrm{i}}\right)$ & $\mathrm{Q}\left(\mathrm{s}_{\mathrm{i}}\right)$ & $\mathrm{R}\left(\mathrm{s}_{\mathrm{i}}\right) \cap \mathrm{Q}\left(\mathrm{s}_{\mathrm{i}}\right)$ & Level \\
\hline & Reachability Set & Antecedent Set & & \\
\hline $\mathrm{a}$ & a, b, c, d,e, f, g, h, i, j, k, l, m, n, o, p, q, r, s, t, u & $\mathrm{a}$ & $\mathrm{a}$ & 8 \\
\hline $\mathrm{b}$ & b, c, e, f, g,h, i, j, k, l, m, n, o, p, q, r, s, t, u & $\mathrm{a}, \mathrm{b}$ & $\mathrm{b}$ & 7 \\
\hline c & $c, g, i, j, n, o, p, q, r, s, t, u$ & $\mathrm{a}, \mathrm{b}, \mathrm{c}$ & $\mathrm{c}$ & 5 \\
\hline $\mathrm{d}$ & $\mathrm{d}, \mathrm{f}, \mathrm{g}, \mathrm{j}, \mathrm{k}, \mathrm{l}, \mathrm{m}, \mathrm{n}, \mathrm{o}, \mathrm{p}, \mathrm{q}, \mathrm{r}, \mathrm{s}, \mathrm{t}, \mathrm{u}$ & $\mathrm{a}, \mathrm{d}$ & $\mathrm{d}$ & 5 \\
\hline $\mathrm{e}$ & e, f, g, h, i, j, k, m, n, o, p, q, r, s, t, u & $\mathrm{a}, \mathrm{b}, \mathrm{e}$ & $\mathrm{e}$ & 6 \\
\hline $\mathrm{f}$ & $\mathrm{f}, \mathrm{g}, \mathrm{k}, \mathrm{m}, \mathrm{p}, \mathrm{r}, \mathrm{s}, \mathrm{t}, \mathrm{u}$ & a, b, d, e, f & $\mathrm{f}$ & 4 \\
\hline g & $\mathrm{g}, \mathrm{t}, \mathrm{u}$ & a, b, c, d,e, f, g & g & 3 \\
\hline $\mathrm{h}$ & $\mathrm{h}, \mathrm{i}, \mathrm{j}, \mathrm{n}, \mathrm{o}, \mathrm{p}, \mathrm{q}, \mathrm{r}, \mathrm{s}, \mathrm{t}, \mathrm{u}$ & $\mathrm{a}, \mathrm{b}, \mathrm{e}, \mathrm{h}$ & $\mathrm{h}$ & 5 \\
\hline $\mathrm{i}$ & $\mathrm{i}, \mathrm{j}, \mathrm{n}, \mathrm{o}, \mathrm{p}, \mathrm{q}, \mathrm{r}, \mathrm{s}, \mathrm{t}, \mathrm{u}$ & $\mathrm{a}, \mathrm{b}, \mathrm{c}, \mathrm{e}, \mathrm{h}, \mathrm{i}$ & $\mathrm{i}$ & 4 \\
\hline $\mathrm{j}$ & $\mathrm{j}, \mathrm{u}$ & $\mathrm{a}, \mathrm{b}, \mathrm{c}, \mathrm{d}, \mathrm{e}, \mathrm{h}, \mathrm{i}, \mathrm{j}$ & $\mathrm{j}$ & 2 \\
\hline $\mathrm{k}$ & $\mathrm{k}, \mathrm{t}, \mathrm{u}$ & $\mathrm{a}, \mathrm{b}, \mathrm{d}, \mathrm{e}, \mathrm{f}, \mathrm{k}$ & $\mathrm{k}$ & 3 \\
\hline 1 & $\mathrm{l}, \mathrm{m}, \mathrm{n}, \mathrm{o}, \mathrm{p}, \mathrm{q}, \mathrm{r}, \mathrm{s}, \mathrm{t}, \mathrm{u}$ & a, b, d, l & $\mathrm{l}$ & 4 \\
\hline $\mathrm{m}$ & $\mathrm{m}, \mathrm{r}, \mathrm{u}$ & $\mathrm{a}, \mathrm{b}, \mathrm{d}, \mathrm{e}, \mathrm{f}, \mathrm{l}, \mathrm{m}$ & $\mathrm{m}$ & 3 \\
\hline $\mathrm{n}$ & $\mathrm{n}, \mathrm{s}, \mathrm{u}$ & a, b, c, d, e, h, i, l, n & $\mathrm{n}$ & 3 \\
\hline o & $\mathrm{o}, \mathrm{p}, \mathrm{u}$ & a, b, c, d, e, h, i, l, o & 0 & 3 \\
\hline $\mathrm{p}$ & $\mathrm{p}, \mathrm{u}$ & a, b, c, d, e, f, h, i, l, o, p & $\mathrm{p}$ & 2 \\
\hline$q$ & $\mathrm{q}, \mathrm{s}, \mathrm{u}$ & $\mathrm{a}, \mathrm{b}, \mathrm{c}, \mathrm{d}, \mathrm{e}, \mathrm{h}, \mathrm{i}, \mathrm{l}, \mathrm{q}$ & $\mathrm{q}$ & 3 \\
\hline $\mathrm{r}$ & $\mathrm{r}, \mathrm{u}$ & a, b, c, d, e, f, h, i, l, m, r & $\mathrm{r}$ & 2 \\
\hline $\mathrm{s}$ & $\mathrm{s}, \mathrm{u}$ & $\begin{array}{l}\text { a, b, c, d, e, f, h, i, l, n, q, } \\
\text { s }\end{array}$ & $\mathrm{s}$ & 2 \\
\hline $\mathrm{t}$ & $\mathrm{t}, \mathrm{u}$ & $\begin{array}{l}\text { a, b, c, d, e, f, g, h, i, k, l, } \\
t\end{array}$ & $\mathrm{t}$ & 2 \\
\hline $\mathrm{u}$ & $\mathrm{u}$ & $\begin{array}{l}\text { a, b, c, d, e, f, g, h, i, j, k, } \\
\text { l, m, n, o, p, q, r, s, t, u }\end{array}$ & $\mathrm{u}$ & 1 \\
\hline
\end{tabular}


Step 5. The learning path and map becomes concrete as shown in Fig. 2. Arrows indicate a learning path with direction of learning progress. On the left side of Fig. 2, levels display a sequential learning from easy to difficult from 8 to 1 . After a teacher identified the learning order matching his/her mental model, then he/she adopted the adjacency matrix for later use in the modified Delphi method. Step 2 to 5 were repeated until all teachers arrived at the consensus.

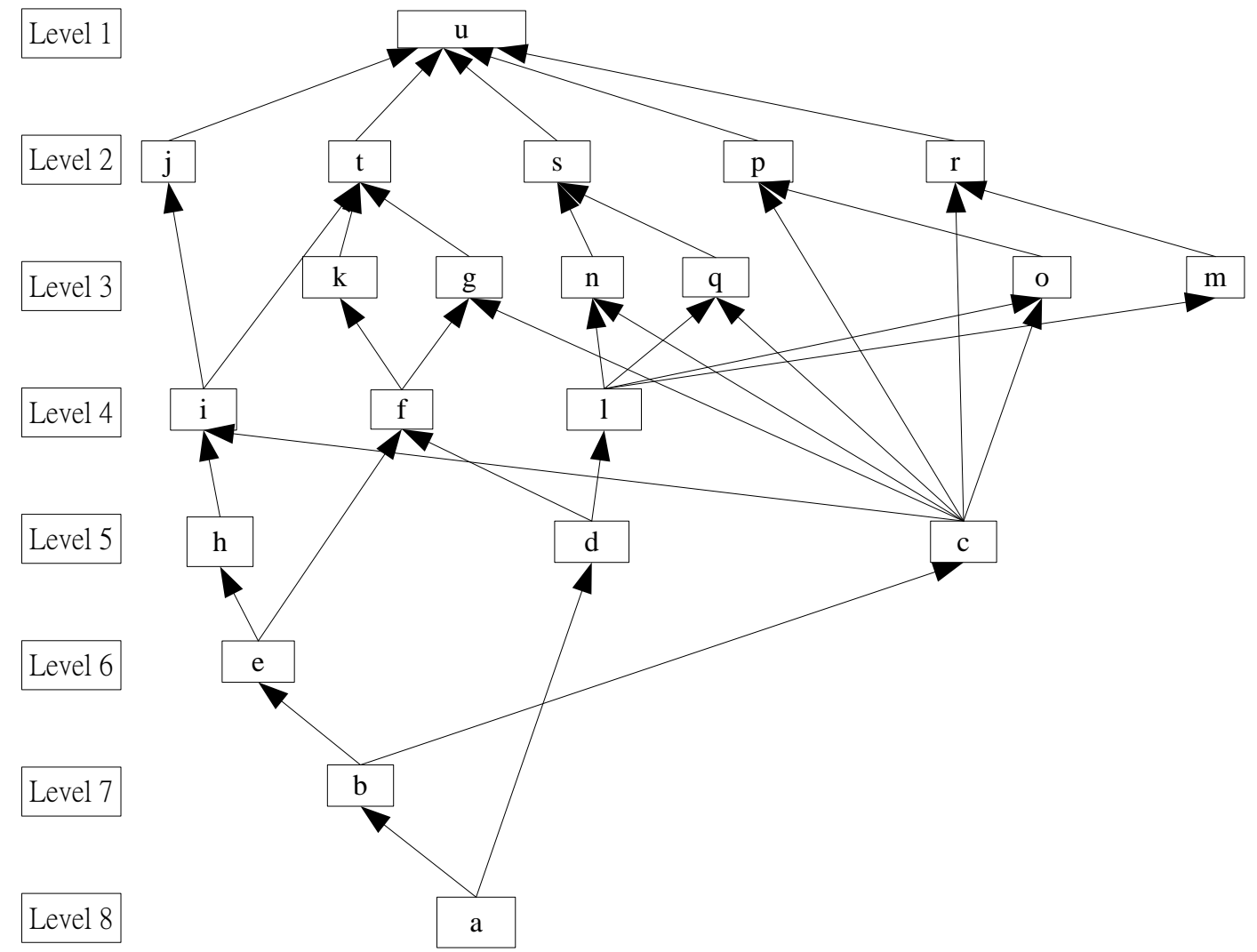

Fig. 2 Interpretive structural model

\subsubsection{Developing teaching materials and implementing class teaching}

A teaching essentials hierarchy diagram (Fig. 2) was structured under certain principles. According to the correlation and learning sequence between essentials, the templates in unit design were considered a more practical way of imparting knowledge than conventional knowledge transferring practice, and thus offering design efficiency and flexibility [6]. The templates provide learning samples and corresponding operating practices. This course conducted four design project units to train capabilities of integrating and applying. These ad hoc design projects apply various functions related to unit objectives and control equal proportions of the fundamental and deeper concepts to avoid early abandonment due to the difficulty. The teaching essentials of four design projects are listed in Table 3.

Table 3 Analysis of teaching unit design element essentials

\begin{tabular}{|c|c|c|c|c|c|c|c|c|c|c|c|c|c|c|c|c|c|c|c|c|}
\hline \multirow{2}{*}{ Task } & \multirow{2}{*}{ Topic } & \multicolumn{19}{|c|}{ Essentials } \\
\hline & & $\mathbf{a}$ & b & c & d & e & f & g & h & i & j & $\mathbf{k}$ & 1 & m & $\mathbf{n}$ & $\mathbf{0}$ & $\mathbf{p}$ & $\mathbf{q}$ & $\mathbf{r}$ & $\mathbf{s}$ \\
\hline $\mathrm{I}$ & The growth game & $\mathrm{X}$ & $\mathrm{X}$ & $\mathrm{X}$ & $\mathrm{X}$ & $\mathrm{X}$ & $\mathrm{X}$ & & $\mathrm{X}$ & $\mathrm{X}$ & & & $\mathrm{X}$ & $\mathrm{X}$ & & & & & & \\
\hline II & Rhythm game & $\mathrm{X}$ & $\mathrm{X}$ & $\mathrm{X}$ & $\mathrm{X}$ & $\mathrm{X}$ & $\mathrm{X}$ & $\mathrm{X}$ & & $\mathrm{X}$ & & & $\mathrm{X}$ & & & & & $\mathrm{X}$ & & \\
\hline III & Painting and Print & $\mathrm{X}$ & $\mathrm{X}$ & $\mathrm{X}$ & $X$ & $X$ & & & & $X$ & & & $\mathrm{X}$ & & & $\mathrm{X}$ & & & & $\mathrm{X}$ \\
\hline IV & Video and Animation & $\mathrm{X}$ & $\mathrm{X}$ & $\mathrm{X}$ & $\mathrm{X}$ & $\mathrm{X}$ & $\mathrm{X}$ & & & & & $\mathrm{X}$ & $\mathrm{X}$ & & & & & $\mathrm{X}$ & & \\
\hline
\end{tabular}

Task I-IV are projects in teaching unit; " $X$ " represents the adopted elements. 


\section{Evaluating implementation results}

After implementing “Structural Teaching Materials of Multimedia Programming Course”, there were several phenomena observed as below:

\subsection{Adaptive learning plan}

Multimedia design works combine design aesthetic and logic programming. In Taiwan, multimedia students with artistic design background possess the expressive ability of creativity and aesthetics; however, programming from scratch challenges their knowledge and skills of logical thinking. One of the interviewees, Peng, thinks: "With teaching students with different background, so would the sequence of teaching be varied. Multimedia design students rarely have overall programming concepts. In teaching, procedure will be the priority of programming, then bringing in the object-oriented concepts." Teaching objects influence teacher's decision on the sequence of teaching. This research combined the ISM and the modified Delphi method to examine the programming teachers' experience and to analyze structural teaching elements in the digital content design department at Ling Tung University. Every teacher arranged the advanced content in later part of the sequence of teaching, and the object-oriented concept took place in the final section. This corresponds to Peng's view of the sequence of teaching. By using such a methodology, this research can establish an appropriate learning path fitting students' background, and constructing their adaptive learning and structured knowledge. The findings of this study can provide teachers a learning model of programming, planning design related courses with sequential teaching materials and strategy.

\subsection{Instructional scaffolding}

According to the features of the teaching essentials in the learning path and map, the teacher led in teaching content one-by-one, applied the order and relation between teaching elements in his/her course design, and took into account the surface and deep learning. Through reading the feedback information of learning and analyzing teaching essentials, the teacher could quickly identify the reasons of poor comprehension. The teacher could then timely guide students or supplement corresponding concept knowledge. The established instructional scaffolding (Fig. 3) could contribute to student's learning and the posted messages proved the need of further guiding and instructing of essential elements.

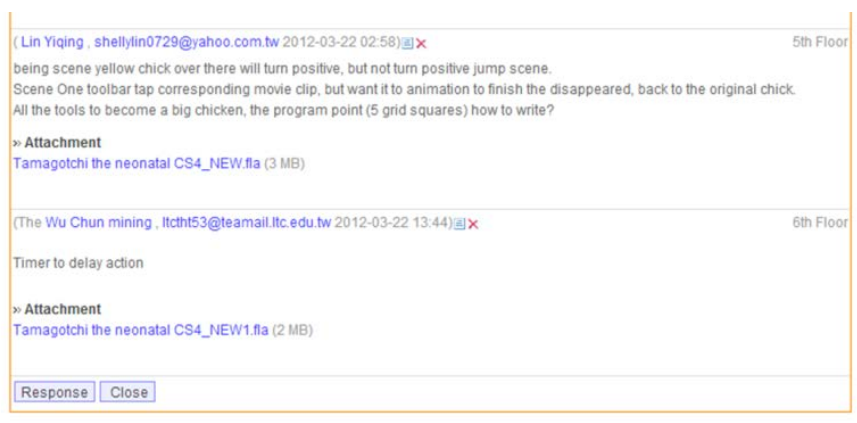

Fig. 3. Discussion forums

\section{Conclusion}

ISM is an effective course designing tool. Based on different criteria (learning courses and learning objectives) and the modified Delphi method, it is useful to analyze the learning essentials categories, relations, and sequence of teaching. The hierarchy diagram of structural teaching essentials provides a 
blueprint for teaching content design. It develops materials to identify and understand the learning difficulty from student's feedback, by which the teacher can give immediate counseling and supplemental materials of concept knowledge, and thus to achieve effective learning in students. Such an integration of teaching design related to longitudinal learning can avoid fragmental knowledge, and stimulate student's comprehensive application of higher order thinking skills and adaptive learning.

\section{References}

1. Hasson, F., Keeney, S., \& McKenna, H. (2000). Research guidelines for the Delphi survey technique. Journal of Advanced Nursing, 32(4), 1008-1015.

2. Hendricks, C. (2006). Improving schools through action research: Boston: Allyn \& Bacon.

3. Jiwei, X., \& Bo, N. (2011, 20-22 Aug. 2011). Analysing the curriculum of digital media with the method of ISMWith a look at educational technology of undergraduate in non-normal universities. Paper presented at the Information Technology and Artificial Intelligence Conference (ITAIC), 2011 6th IEEE Joint International.

4. Kannan, G., Pokharel, S., \& Sasi Kumar, P. (2009). A hybrid approach using ISM and fuzzy TOPSIS for the selection of reverse logistics provider. Resources, Conservation and Recycling, 54(1), 28-36.

5. Khan, G. F., Moon, J., Rhee, C., \& Rho, J. J. (2010). E-government skills identification and development: Toward a staged-based user-centric approach for developing Countries. Asia Pacific Journal of Information Systems, 20(1), $1-31$.

6. Kolfschoten, G., Lukosch, S., Verbraeck, A., Valentin, E., \& Vreede, G. J. (2010). Cognitive learning efficiency through the use of design patterns in teaching. Computers \& Education, 54(3), 652-66.

7. Malone, D. W. (1975). An introduction to the application of interpretive structural modeling. Proceedings of the IEEE, 63(3), 397-404.

8. Mills, G. E. (2007). Action Research: A Guide for the Teacher Researcher (3rd ed.): Southern Oregon University.

9. Ning, Y., \& Yanfeng, W. (2011, 8-10 Aug. 2011). Risk analysis of EPC project based on ISM. Paper presented at the Emergency Management and Management Sciences (ICEMMS), 2011 2nd IEEE International Conference.

10. Norcross, J. C., Hedges, M., \& Prochaska, J. O. (2002). The face of 2010: A Delphi poll on the future of psychotherapy. Professional Psychology: Research and Practice, 33(3), 316.

11. Preble, J. F. (1983). Public sector use of the Delphi technique. Technological Forecasting and Social Change, 23(1), 75-88.

12. Sagor, R. (2010). The Action Research Guidebook: A Four-Stage Process for Educators and School Teams: Corwin Press.

13. Saizarbitoria, I. H. (2006). How quality management models influence company results—Conclusions of an empirical study based on the Delphi method. Total Quality Management \& Business Excellence, 17(6), 775-794.

14. Sato, T. (1979). Determination of hierarchical networks of instructional units using the interpretive structural modeling method. Japan Journal of Educational Technology, 4(1), 9-16.

15. Turoff, M., Hiltz, S. R., Yao, X., Li, Z., Wang, Y., \& Cho, H. K. (2006). Online collaborative learning enhancement through the Delphi Method. Turkish Online Journal of Distance Education, 7(2), 66-79.

16. Van Zolingen, S. J., \& Klaassen, C. A. (2003). Selection processes in a Delphi study about key qualifications in senior secondary vocational education. Technological Forecasting and Social Change, 70(4), 317-340.

17. Warfield J. N. (1974). Structuring complex systems. Columbus, Ohio: Battelle Memorial Institute.

18. Warfield J. N. (1976). Societal systems: Planning, policy, and complexity. New York: Wiley. 